Pacific Journal of Mathematic 


\title{
A PROOF OF THE FINITE GENERATION OF INVARIANTS OF A NORMAL SUBGROUP
}

\section{JoHN BRENDAN SULLIVAN}

\begin{abstract}
A fundamental theorem in the development of the quotient theory of an affine algebraic group $G$ shows that the coordinate functions invariant under a normal subgroup form a finitely generated algebra. We show that this theorem follows from the finite field generation of the quotient field of the algebra of invariant coordinate functions in the connected case.
\end{abstract}

Notation. Let $K$ be an algebraically closed field and $A$ an integral domain Hopf algebra over $K$. Denote by $[A]$ the field of fractions of $A$, and by $G(A)$ the group of $K$-algebra morphisms from $A$ to $K$. There is the natural left action (translation) of $G(A)$ on $A$, denoted by $(\cdot)$.

For the sake of completeness, we include a proof of a known proposition for fields:

Proposition 0. $K \subset L \subset E$ fields. If $E$ is finitely generated as a field over $K$, then $L$ is finitely generated as a field over $K$.

Proof. Let $x_{1}, \cdots, x_{t}$ be a transcendence basis for $L$ over $K$. We will see that $L$ is a finite extension of $\ell=K\left(x_{1}, \cdots, x_{t}\right)$. Let $y_{1}, \cdots$, $y_{n}$ be a transcendence basis for $E$ over $\ell$; since $E$ is finitely generated over $K, E$ is a finite extension of $\ell\left(y_{1}, \cdots, y_{n}\right)$. Since $\ell\left(y_{1}, \cdots, y_{n}\right)$ is purely transcendental over $\ell$ and $L$ is algebraic over $\ell, \ell\left(y_{1}, \cdots, y_{n}\right)$ and $L$ are linearly disjoint over $\ell$. Therefore, the dimension of $E$ over $\ell\left(y_{1}, \cdots, y_{n}\right)$ is at least as large as the dimension of $L$ over $\ell$. So $L$ is finite over $\ell$ and $L$ is finitely generated over $K$.

Proposition 1. Let $A_{1} \subset A$ be domain Hopf algebras. Then $\left[A_{1}\right] \cap A=A_{1}$.

Proof. Let $f=a / b$ be an element of $\left[A_{1}\right] \cap A$, where $a, b \in A_{1}$. For the purpose of demonstrating this proposition, we may suppose that $A$ is generated as a Hopf algebra by $a, b$, and $f$ and that $A_{1}$ is generated by $a$ and $b$. Let $M$ be the $K$-linear span of $G(A) \cdot f ; M$ is a finite-dimensional $G(A)$-invariant subspace of $\left[A_{1}\right] \cap A$. Let $I \subset$ $A_{1}$ be the ideal $\left\{c \in A_{1} \mid c M \subset A_{1}\right\}$; since $M$ is finite-dimensional, $I \neq(0)$. If $I=A_{1}$, then $f \in A_{1}$, as was to be shown. Otherwise, from $g \cdot M=$ $M$ and $g \cdot A_{1}=A_{1}$ for $g \in G(A)$, it follows that $g \cdot I=I$; so, $I$ is a 
$G(A)$-module. Moreover, since $I \subset A_{1}$ and $G(A)$ separates the points of $A_{1}$, we have $G\left(A_{1}\right) \cdot I=I$. Since $I \neq A_{1}$, by the Nullstellensatz there is an element $x$ of $G\left(A_{1}\right)$ which vanishes on $I$. Therefore, $0=$ $x(I)=x\left(G\left(A_{1}\right) \cdot I\right)=\left(x \cdot G\left(A_{1}\right)\right)(I)=G\left(A_{1}\right)(I)$. By the Nullstellensatz, $I=(0)$. This contradicts $I \neq(0)$.

Proposition 2. If $A_{1} \subset A$ are domain Hopf algebras and $\left[A_{1}\right]=$ $[A]$, then $A_{1}=A$.

Proof. $A_{1}=\left[A_{1}\right] \cap A=A$.

THEOREM. For $A \subset B$ domain Hopf algebras, if $B$ is a finitely generated $K$-algebra, then $A$ is a finitely generated $K$-algebra.

Proof. Since $B$ is finitely generated as a $K$-algebra, $[B]$ is finitely generated as a field over $K$. By Proposition 0, $[A]$ is finitely generated as a field over $K$. Let $a_{1}, \cdots, a_{n}$ be field generators for [A] where $a_{i} \in A$. Let $A_{1}$ be the sub-Hopf algebra of $A$ generated by $a_{1}, \cdots, a_{n}$; so, $\left[A_{1}\right]=[A]$. By Proposition $2, A_{1}=A$. Therefore, $A$ is finitely generated as a $K$-algebra.

For $G(B)$ a connected affine algebraic group with domain Hopf algebra $B$ of coordinate functions and $H$ a normal subgroup, the subalgebra $B^{H}$ of $B$ of $H$-invariant elements is a sub-Hopf algebra; since $B$ is finitely generated, so is $B^{H}$ by the theorem.

From this point, the extension to the nonconnected case is given in $[1, \mathrm{p} .38]$.

\section{REFERENCE}

1. G. Hochschild, Introduction to Affine Algebraic Groups, Holden-Day, San Francisco, 1971.

Received February 2, 1973.

UNIVERSity of CALIForNiA, BERKELEy 


\section{PACIFIC JOURNAL OF MATHEMATICS}

\section{EDITORS}

RICHARD ARENS (Managing Editor)

University of California

Los Angeles, California 90024
J. DUGUNDJI*

Department of Mathematics

University of Southern California

Los Angeles, California 90007

D. Gilbarg and J. Milgram

Stanford University

Stanford, California 94305
University of Washington

Seattle, Washington 98105

ASSOCIATE EDITORS
E. F. BECKENBACH
B. H. NeumanN
F. WoLF
K. YosHIDA

\section{SUPPORTING INSTITUTIONS}

\author{
UNIVERSITY OF BRITISH COLUMBIA \\ CALIFORNIA INSTITUTE OF TECHNOLOGY \\ UNIVERSITY OF CALIFORNIA \\ MONTANA STATE UNIVERSITY \\ UNIVERSITY OF NEVADA \\ NEW MEXICO STATE UNIVERSITY \\ OREGON STATE UNIVERSITY \\ UNIVERSITY OF OREGON \\ OSAKA UNIVERSITY
}

\author{
UNIVERSITY OF SOUTHERN CALIFORNIA \\ STANFORD UNIVERSITY \\ UNIVERSITY OF TOKYO \\ UNIVERSITY OF UTAH \\ WASHINGTON STATE UNIVERSITY \\ UNIVERSITY OF WASHINGTON
* * * *
AMERICAN MATHEMATICAL SOCIETY \\ NAVAL WEAPONS CENTER
}

The Supporting Institutions listed above contribute to the cost of publication of this Journal, but they are not owners or publishers and have no responsibility for its content or policies.

Mathematical papers intended for publication in the Pacific Journal of Mathematics should be in typed form or offset-reproduced, (not dittoed), double spaced with large margins. Underline Greek letters in red, German in green, and script in blue. The first paragraph or two must be capable of being used separately as a synopsis of the entire paper. Items of the bibliography should not be cited there unless absolutely necessary, in which case they must be identified by author and Journal, rather than by item number. Manuscripts, in duplicate if possible, may be sent to any one of the four editors. Please classify according to the scheme of Math. Rev. Index to Vol. 39. All other communications to the editors should be addressed to the managing editor, or Elaine Barth, University of California, Los Angeles, California, 90024.

100 reprints are provided free for each article, only if page charges have been substantially paid. Additional copies may be obtained at cost in multiples of 50 .

The Pacific of Journal Mathematics is issued monthly as of January 1966. Regular subscription rate: $\$ 72.00$ a year (6 Vols., 12 issues). Special rate: $\$ 36.00$ a year to individual members of supporting institutions.

Subscriptions, orders for back numbers, and changes of address should be sent to Pacific Journal of Mathematics, 103 Highland Boulevard, Berkeley, California, 94708.

PUBLISHED BY PACIFIC JOURNAL OF MATHEMATICS, A NON-PROFIT CORPORATION

Printed at Kokusai Bunken Insatsusha (International Academic Printing Co., Ltd.), 270, 3-chome Totsuka-cho, Shinjuku-ku, Tokyo 160, Japan.

* C. R. DePrima California Institute of Technology, Pasadena, CA 91109, will replace J. Dugundji until August 1974.

Copyright (C) 1973 by Pacific Journal of Mathematics

Manufactured and first issued in Japan 


\section{Pacific Journal of Mathematics}

\section{Vol. 51, No. $2 \quad$ December, 1974}

Robert F. V. Anderson, Laplace transform methods in multivariate spectral theory .................................................. 339

William George Bade, Two properties of the Sorgenfrey plane . . . . . . . . . . . . 349

John Robert Baxter and Rafael Van Severen Chacon, Functionals on continuous

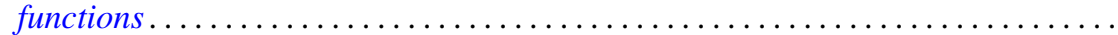

Phillip Wayne Bean, Helly and Radon-type theorems in interval convexity

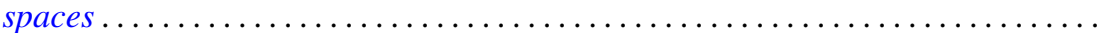

James Robert Boone, On k-quotient mappings $\ldots \ldots \ldots \ldots \ldots \ldots \ldots \ldots \ldots$

Ronald P. Brown, Extended prime spots and quadratic forms . . . . . . . . . . . .

William Hugh Cornish, Crawley's completion of a conditionally upper continuous lattice .............................................

Robert S. Cunningham, On finite left localizations ...................

Robert Jay Daverman, Approximating polyhedra in codimension one spheres

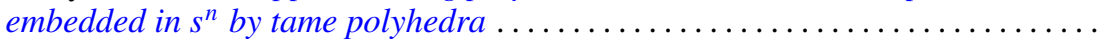

Burton I. Fein, Minimal splitting fields for group representations . . . . . . . . . . . .

Peter Fletcher and Robert Allen McCoy, Conditions under which a connected

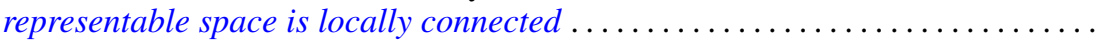

Jonathan Samuel Golan, Topologies on the torsion-theoretic spectrum of a noncommutative ring...

Manfred Gordon and Edward Martin Wilkinson, Determinants of Petrie matrices.

Alfred Peter Hallstrom, A counterexample to a conjecture on an integral condition for determining peak points (counterexample concerning peak points)........

E. R. Heal and Michael Windham, Finitely generated $F$-algebras with applications to Stein manifolds.

Denton Elwood Hewgill, On the eigenvalues of a second order elliptic operator in an unbounded domain ............................

Charles Royal Johnson, The Hadamard product of $A$ and $A^{*}$.

Darrell Conley Kent and Gary Douglas Richardson, Regular completions of Cauchy spaces.

Alan Greenwell Law and Ann L. McKerracher, Sharpened polynomial approximation

Bruce Stephen Lund, Subalgebras of finite codimension in the algebra of analytic functions on a Riemann surface. .

Robert Wilmer Miller, TTF classes and quasi-generators . .

Roberta Mura and Akbar H. Rhemtulla, Solvable groups in which every maximal partial order is isolated ....

Isaac Namioka, Separate continuity and joint continuity...

Alan Saleski, Entropy of self-homeomorphisms of statistical pseudo-metric

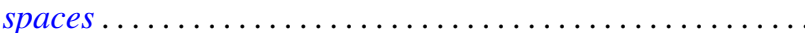

H. A. Seid, Cyclic multiplication operators on $L_{p}$-spaces .....

H. B. Skerry, On matrix maps of entire sequences ............

John Brendan Sullivan, A proof of the finite generation of invariants of a normal

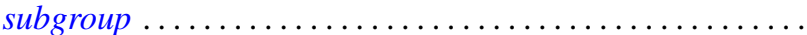

John Griggs Thompson, Nonsolvable finite groups all of whose local subgroups are

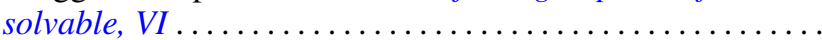

